\title{
Russian Reception of Christopher Marlowe's Creative Work in the 1830 - 1850-s
}

Dmitry Nikolayevich Zhatkin

\author{
Department of Translation and Methods of Translation, Penza State Technological University,
} Penza, Russian Federation

Anna Anatolyevna Ryabova

Department of Translation and Methods of Translation, Penza State Technological University, Penza, Russian Federation

\section{Doi:10.5901/mjss.2015.v6n3s3p391}

\section{Abstract}

The article comprehends circumstances of the appearance of a wide range of translated articles (mostly anonymous, in some cases with the names of F.Eckstein, Th.Show) in the Russian press in the 1830 - 1850-s in which a general characteristics of the English dramatist Christopher Marlowe's creative work in the context of his epoch was presented for the first time. It also gives short opinions of Christopher Marlowe which appeared in the 1840 - 1850-s in the articles on literary criticism and publicistic articles, created by the leading Russian writers I.S. Turgenev ("Faust, a Tragedy. Goethe's Work. The Translation of the First Part and Summary of the Second One. M.Vronchenko. 1844. Saint-Petersburg", 1845), N.A.Nekrasov ("From the Editor", 1850), A.V.Druzhinin (letters XXIII and XXV of the cycle "Letters of the Nonresident Subscriber", 1851; an introduction to the translation of Shakespeare's "King Lear", 1856). The article presents the experience of Christopher Marlowe's creative work study in the history of Russian literature of the second part of the XIXth century allowing to comprehend circumstances of genesis and development of interest to his creative work among Russian writers, translators, literary critics, literature researchers, art critics, explain his poetic's elements penetration into Russian literature and culture. In the process of the analysis the articles of the given period devoted to the development of Elizabethan drama are taken into account; the use of these materials allowed to comprehend Marlowe's works in important for their understanding historical and literature context.

Keywords: Marlowe, drama, intercultural communication, literary criticism, literary translation, Russian-English literary, cultural and historical relations, comparative study.

\section{Introduction}

The article considers facts of understanding a great dramatist of the Elizabethan period Christopher Marlowe's creative work by Russian literary critics, literature researchers and writers in the 1830 - 1850-s within the study of reception of Marlowe in Russia in the XIX - at the beginning of the XXIst century. It aims to systematize separate data concerning reception of Marlowe by F.Eckstein, Ph.Chalse, Th.Show, W.K.Kuchelbecker, I.S.Turgenev, M.L.Mikhailov, N.A.Nekrasov, A.V.Druzhinin, M.A.Tulov, A.I.Linnichenko, anonymous authors and find interrelations in English and Russian literature.

With all significance of Russian writers, translators and literary critics' attention to Christopher Marlowe's creative work the problems relating to the study of reception of the English dramatist's works in Russia remain unexplored. Alongside with this, Christopher Marlowe is one of those few English authors whose creative heritage is represented in the Russian language in all its variety (the only work which is not translated into Russian is the tragedy "Didona, Queen of Carthage"), moreover, some works (such as "The Tragical History of Doctor Faustus", "The Passionate Shepherd to his Love" and others) are known in numerous interpretations.

The article adds to the study of foreign writers' creative work in the context of Russian literature and literary translation history. It shows genesis and development of interest to Marlowe among Russian writers, translators, literary critics, literature and art researchers. It bases on studies of Russian-English literature, cultural, historical relations by Yu.D.Levin (Levin, 1985), D.N.Zhatkin (Zhatkin, 2008) and others.

While speaking about many century interest of Russian literature to Christopher Marlowe's creative work it should be noted that researchers had been aiming to find its beginnings in the play of the XVIIth century "Temir-Aksakov Action" and A.S.Pushkin's works. However, neither the former hypothesis, nor the latter one got necessary reasoning. Actually, the 1830 - 1850-s were the time of genesis and swift development of Russian interest to Christopher Marlowe, to whom in the 1820-s only few translated articles were devoted in Russian press. In fact, during the period under consideration Russian notions about Marlowe were formed and expressed in Russian writers, translators, literary critics' works. 


\section{Literature Review}

The article appeared due to significant works of predecessors - outstanding Russian literature and art researchers Alexander N. Veselovskiy (Veselovskiy, 1940), Alexey N. Veselovskiy (Veselovskiy, 1906), V.M.Zhirmunskiy (Zhirmunskiy, 1979), A.K.Dzhivelegov (Dzhivelegov, 1943), M.P.Alekseyev (Alekseyev, 1982), N.I.Balashov (Balashov, 1998), M.L.Gasparov (Gasparov, 1989), A.A.Anikst (Anikst, 1965), Yu.D.Levin (Levin, 1985), V.E.Bagno (Bagno, 2006), A.V.Bartoshevich (Bartoshevich, 1985), researches in the sphere of theory and history of Russian literary translation and Russian translated belles-lettres (A.V.Fedorov (Fedorov, 1983), E.G.Etkind (Etkind, 1973), F.G.Ovchinnikova (Ovchinnikova, 1965), A.N.Girivenko (Girivenko, 2002), L.L.Nelyubin \& G.T.Khukhuni (Nelyubin \& Khukhuni, 2008) and others), Russian-English literary, cultural and historical relations (G.N.Boyadzhiev (Boyadzhiev, 1973), L.E.Pinskiy (Pinskiy, 1971), D.N.Zhatkin (Zhatkin, 2008) and others), history of English literature (N.I.Storozhenko (Storozhenko, 1872), M.M.Morozov (Morozov, 1941), A.A.Smirnov (Smirnov, 1963), R.M.Samarin (Samarin, 1964), Yu.F.Shvedov (Shvedov, 1975), G.V.Anikin \& N.P.Mikhalskaya (Anikin \& Mikhalskaya, 1975), A.T.Parfenov (Parfenov, 1964), A.N.Gorbunov (Gorbunov, 2006), N.E.Mikeladze (Mikeladze, 2005) and others).

The general idea of the creative work of Christopher Marlowe as Shakespeare's predecessor and specifics of Elizabethan drama was formed due to foreign researchers' works R.E.Knoll (Knoll, 1969), P.H.Kocher (Kocher, 1962), C.B.Kuriyama (Kuriyama, 1980), J.B.Leishman (Leishman, 1962), H.Levin (Levin, 1964), J.Weil (Weil, 1977).

\section{Materials and Methods}

While considering sources base and methodology of research work the sources and approaches chosen for solving given scientific tasks should be mentioned separately.

We relied on primary sources (materials found in archives, museums, libraries), secondary sources (the works of those who have written history of literature) and recollections (autobiographies, memoirs, letters, diaries).

The analysis involves opinions expressed in different sources, among which are articles on literary criticism and publicistic articles of the 1830 - 1850-s, materials in textbooks, letters, diaries and notes. Alongside with this, the whole layer of later works in one way or another concerning the problems of the given research work is taken into account, not only works in the sphere of comparative-historical literary criticism, but data of expositors in complete definitive editions of Russian writers' works.

Search and collection of the material for the analysis was carried out in the leading Russian libraries and archives, including the Russian State Library, State Public Historical Library, Russian National Library funds preserving the rarest materials. The task of the facts systematizing with maximum comprehension, including considering insignificant facts and mentions, was set and successfully solved. Letters, diaries, memoirs materials, testimony of contemporaries allowed to correct opinions on the subject of the research work significantly.

While interpreting data we used such methods as comparative-historical, examining historical literature events in England at the end of the XVIth century and Russia in the 1830 - 1850-s, biographical, concerning facts of English and Russian writers' biographies, typological, including classification, generalization, explanation.

Methodologically, the research work bases on fundamental works of predecessors in the sphere of comparativehistorical literary criticism, in particular, works of Alexander N. Veselovskiy (Veselovskiy, 1940), V.M.Zhirmunskiy (Zhirmunskiy, 1979), M.P.Alekseyev (Alekseyev, 1982). Alongside with this, an important part in the approaches formation was played by works of Russian philologists - researchers of Russian translated belles-lettres history, Russian poetry translation - A.N.Girivenko (Girivenko, 2002), L.L.Nelyubin \& G.T.Khukhuni (Nelyubin \& Khukhuni, 2008), G.G.Gachechiladze (Gachechiladze, 1980) and others.

\section{Results}

In the process of the article preparation more than 200 sources supposedly containing facts relating to the problem were considered. However, the majority of them had no information, or replicated oftentimes published data. Finally, about 25 printed works in Russian pre-revolutionary press and researches concerning the problem of reception of Marlowe's creative work in Russia were chosen for the holistic analysis.

A surge of interest in English drama of the Elizabethan period caused the appearance of a wide range of translated articles in Russian press in the 1830 - 1850-s. It is particularly necessary to note among them the work of F.Eckstein, a philosopher and publicist, one of the French correspondents of A.I.Turgenev (Zaborov, 1978), "About Drama Poetry in England before Shakespeare and about Shakespearean Drama", published in "Moskovskiy Telegraf" ("Moscow 
Telegraph") in 1831 ([Eckstein], 1831). The response to this article was W.K.Kuchelbecker's diary note dating April 18, 1834 mostly showing those contradictory feelings of a thoughtful reader F.Eckshtein's considerations were able to cause: "A long-winded introduction to this article made me expect it to be more complete. It is evident that I, a true protestant, wouldn't agree with Eckshtein's catholic paradoxes, even a catholic would hardly agree with them, otherwise he is absolutely blind $\langle\ldots\rangle$. There are, by the way, some thoughts I agree with absolutely, for example: "The deeper becomes our industrial enlightenment, the less people feel beauty, love simplicity and truth". Moreover, just the historical aspect in this article is very important <..." (Kuchelbecker, 1979). Translated articles of the French critic Ph.Chalse "Drama Morals of the XVlth Century", published in 1837 in "Moskovskiy Nabludatel" ("Moscow Observer") (Chasle, 1837), and "The English Theatre before Shakespeare", issued in the journal of literature and art "Panteon" ("Pantheon") (Chasle, 1852), also contained opinions about Elizabethan drama.

The predecessor of "Pantheon" - a monthly journal "Pantheon of Russian and All European Theatres", issued in Petersburg in 1840 - 1841, - as early as in 1841 published an anonymous material "About Theatres in London in Shakespeare's time" containing a brief description of the structure and organization of theatres at the end of the XVIth the beginning of the XVIlth centuries, actors' play and spectators' morals (Pantheon of Russian and all European theatres, 1841). In that same year "Literaturnaya Gazeta" ("Literature Newspaper") published an essay "About Dramatists, Shakespeare's Contemporaries" including brief information about John Heywood, Edmund Spenser, Ben Jonson, Philip Massinger, Francis Beaumont and John Fletcher, Christopher Marlowe, James Shirley, John Ford and John Webster and driving to the conclusion that these English authors "composed that great school in which the greatest writers of the following centuries studied and in which all main modern drama and present scenic art foundations were produced" (Literature newspaper, 1841).

In "The Essay on English Literature" by Thomas Show published in "Biblioteka dlya Chteniya" ("Library for Reading") in 1847 Marlowe was named among the founders of new schools in English literature together with Francis Bacon, Thomas More, Philip Sidney, Edmund Spenser, Shakespeare, John Milton, Samuel Butler and John Dryden. Having worked as an actor for a short period of time Marlowe wholly devoted himself to drama in which, according to Th.Show, gave "free rein to his natural inclination to monstrous exaggerations and awful pomposity in the way of expression" (Sha [Show], 1847). Stating that many Shakespeare's allusions are from Marlowe - veiled mockery of the predecessor and his "monstrous dramas", the critic explained his position by evolutionary processes in Elizabethan drama: "Monstrous images and pictures having nothing similar in nature, magniloquence, pomposity, grandiloquence were a true sign of poetic talent at that time while during the epoch of maturity in art when cold analysis of mind replaced bold impulses of unrestrained fantasy the same qualities of a writer are considered to be an unforgivable drawback" (Sha [Show], 1847). Th.Show considered Marlowe's best works to be "The Tragical History of Doctor Faustus", which later influenced J.W.Coethe, and "The Jew of Malta", the "chimerical" image of the main character in which directly preceded the "real image of a person" - Jew-moneylender Shylock - in "The Merchant of Venice" by Shakespeare (Sha [Show], 1847).

I.S.Turgenev also seems to have mentioned Christopher Marlowe in his letter to T.N.Granovskiy dating May 18 (30), 1840: "I have been reading modern German lit<erature>: have got nothing good yet. Markgrafs, Marlows, Mundts, Drexler-Manfreds..." (Turgenev, 1961). However, on close reading of the given fragment it becomes clear that the Russian writer has in his mind literary works of German writers contemporary to him, and "Marlow" (F.Marlow) is a pseudonym of the German poet H.L.Wolfram, the author of the drama poem "Faust" (1839), taken mostly under the influence of Christopher Marlowe (Ch.Marlowe) as a creator of English "Faustus" (Batyuto, 1961). Nevertheless, in the review "Faust, a Tragedy. Goethe's Work. The Translation of the First Part and Summary of the Second One. M.Vronchenko. 1844. Saint-Petersburg" written in 1845 I.S.Turgenev adored the very English dramatist Marlowe announcing his desire to devote an article on literary criticism to his creative work: "The thought to use this type <Faustus> came not to his <Goethe's> mind first; before this one of Shakespeare's predecessors, Marlowe, wrote "Faustus" - an extremely remarkable work about which we will talk to our readers in time..." (Turgenev, 1978). The quotation from the sixth scene of "The Tragical History of Doctor Faustus" in which Seven Deadly Sins appear including Sloth in I.S.Turgenev's letter to P.Viardot dating June 21 - 22 (July 3 - 4), 1847 written in French shows that Marlowe's play was well-known to the Russian writer: "Ce n'est pas pour moi que le Sommeil dit dans le "Faust" de Marlowe: "Heigho! I was begotten on a sunny bank..."' (Turgenev, 2002) [The thing that the dream in Marlowe's "Faustus" speaks is not for me <...>]. As Yu.D.Levin pointed out I.S.Turgenev was interested in Shakespeare's circle, had volumes of works by Ben Jonson, Beaumont and Fletcher, Massinger and other Shakespeare's contemporaries in his library. Unfortunately, they did not survive to this day (Levin, 1965) in contrast to the book "Shakespeare and His Friends, or "The Golden Age" of Merry England" (Paris, 1838) mentioned in the collection of translated materials "Foreign Criticism about Turgenev" (Partnership "Progress of our life", [1908]) as a real edition of Turgenev's library. 
In the XIVth volume of "The Complete Set of Works" by N.G.Chernyshevskiy, issued in 1949, a letter to M.L.Mikhailov dating 1850 (Chernyshevskiy, 1949) was published. In one of its fragments some translation of "Faust" belonging to the addressee was mentioned: "I brought "Faust" to Krayevskiy; he said he would print it with pleasure when censure were not so strict, but now it is not worth bustling about it - the odds are that they will ban it entirely $\langle\ldots\rangle "$ (Chernyshevskiy, 1949). In comments to this letter prepared by B.P.Kozmin it is pointed out that they speak about the translation "The Death of Faustus" from Christopher Marlowe first published in №2 of "Russkoye Slovo" ("Russian Word") in 1860 (Kozmin \& Kusheva, 1949). Later this point of view was disapproved by Yu.D.Levin who stated that N.G.Chernyshevskiy really had in his mind M.L.Mikhailov's translation of both parts of "Faust" by J.W.Coethe (Levin, 1985).

N.A.Nekrasov as an editor and publisher of "Sovremennik" ("Contemporary") considered it important to present new translations of the classics of English literature for Russian readers (Zhatkin, 2008; Zhatkin \& Dolgov, 2007). In 1850 in the note "From the Editor", while announcing the plans of "Sovremennik" ("Contemporary") for 1851, he gave information about the editorial board's intention to print in the journal "the translations of six best works of the most remarkable dramatists, Shakespeare's contemporaries (among which just now it <the editorial board> can name "The Duke of Milan" by Massinger, "The Alchemist" by Ben Jonson, "Faustus" by Marlowe), with a general preface, in which they will describe that state of drama in England, and biographical essays and appreciations of talents of Massinger, Beaumont and Fletcher, B.Jonson, Middleton, Marlowe, Dekker, Peele, Greene and others, - in a word, the whole that pleiad, who surrounded Shakespeare, standing above all of them, but not standing alone" (Nekrasov, 1997). This idea, which appeared, most likely, not without an active influence of V.P.Botkin, the member of staff in Nekrasov's journal and expert of English literature (Melgunov, 1997), was realized only partly in 1853- 1855.

A.V.Druzhinin mentioned Marlowe's name twice in 1851 in "Letters of the Nonresident Subscriber": the first mention in letter XXIII was caused by considerations over the English custom to interrelate some literary works, for example, "David Copperfield" by Ch.Dickens, and their authors' biographies - the custom which "dates back to Marlowe's times" (Druzhinin, 1865b); the second one - in letter XXV - became a response to one of the articles about the famous tragic actor A.S.Yakovlev and presented considerations about the actor's profession: "An actor like Marlowe's Faustus fearlessly sacrifices his future for the sake of the present: his fame is not in future generations, but in applause of contemporaries" (Druzhinin, 1865b). In the introduction to his translation of Shakespeare's tragedy "King Lear" (1856), while giving reasons for "the great controversy" between poetic languages in England and Russia, A.V.Druzhinin named Christopher Marlowe in a row of dramatists, who were the predecessors and contemporaries of Shakespeare, but because of some objective reasons did not share his fame: " $<\ldots>$ any Russian person is an enemy of a phrase, metaphor, pomposity and flamboyancy of a word $\langle\ldots\rangle$. Grandiloquence, and even intensity of speech have always been disadvantages for us $\langle\ldots\rangle$. We will never make peace with the language of Ford, Marston, Marlowe, Webster. Shakespeare is definitely above these dramatists, but Shakespeare has phrases, turns of speech, comparisons, which can touch a modern Russian person" (Druzhinin, 1865a).

The first Russian translations of Marlowe's works appeared later (Zhatkin \& Orlova, 2010), nonetheless, it is necessary to say about the fact that since the 1850-s the name of Marlowe has got into national textbooks on literature. The first textbook in Russian containing information about Christopher Marlowe was "A Guide to Understanding Kinds, Genres and Forms of Poetry" by M.A.Tulov, published in Kiev University printing-house in 1853. It presented the poet as a gloomy, severe personality, who became the victim of his own riotous passions and unrestrained way of life. In M.A.Tulov's reception Marlowe was one of bright representatives of pre-Shakespearean drama poetry which, judging by the appearance of some theatres without governmental support in the 1570 - 1580-s in London, experienced the period of development: "Not every scene can boast such excellent drama talents as Marlowe, Greene, Thomas Heywood, who before Shakespeare enriched English poetry with a wide range of audacious and various forms of both important drama and comic one, plenty of great works" (Tulov, 1853). Noting advantages of other tragedies (first of all "The Jew of Malta" and "Edward II") M.A.Tulov singled out "The Tragical History of Doctor Faustus", saw "a row of superb pictures, sometimes funny, sometimes strikingly awful" in it (Tulov, 1853).

A.I.Linnichenko, the author of "The Course on History of Poetry for Women's Institutes Students and Gymnasiums Students", printed in Kiev in 1860, mostly basing on M.A.Tulov's opinion noted that since the middle of the XVIth century in London "the theatre has been continuously improved and enriched with ingenious works of excellent drama talents as Marlowe, Greene, Thomas Heywood", besides, he considered it necessary to mention only "The Tragical History of Doctor Faustus" among Marlowe's works. It developed "the well-known story of the learned man doctor Faustus, who sold his soul to devil for unlimited power on the earth during 24 years" (Linnichenko, 1860).

In the process of the materials analysis facts having no relation to Marlowe's creative work, but of unquestionable interest for Russian researchers of Shakespeare's creative work, Elizabethan drama as a historical and cultural epoch- 
making phenomenon were fixed. This allowed considering Marlowe's works not in isolation, but in significant for their comprehension literary context, gave additional information for historical poetics of Russian literature.

Consideration of the facts relating to the theme of the research work was realized according to the principle of maximum comprehension and accuracy. Alongside with this, the task not to miss even the most insignificant facts, circumstances, literary details was set. In this relation, in particular, considering opinions of Marlowe's creative work represented in Kiev textbooks of the 1850-s is noteworthy, as well as other individual nuances having no great importance, but in some way complementing the picture of Russian reception, assisting its holistic and many aspect nature.

Fidelity of the given research work is determined by the record of maximum of the materials concerning the given problems and the use of different, sometimes contradictory, points of view which were represented in articles on Russian literary criticism, diaries, letters and memoires. Aiming to avoid preference to certain points of view, the authors of the article cared for comprehension and appreciation of different opinions in a balanced manner.

\section{Discussion}

As we can see, in the 1830 - 1850-s a wide range of translated articles (mostly anonymous, in some cases with the names of F.Eckstein, Th.Show) appeared in the Russian press. They for the first time gave a general characteristics of the English dramatist Christopher Marlowe's creative work in the context of his epoch. What is more, these articles, being devoted not directly to Marlowe, but to the whole English drama of the end of the XVIth century, did not distinguish this author on the background of other numerous Shakespeare's predecessors. At the same period short opinions of Christopher Marlowe appeared in the articles on literary criticism and publicistic articles, created by the leading Russian writers I.S.Turgenev ("Faust, a Tragedy. Goethe's Work. The Translation of the First Part and Summary of the Second One. M.Vronchenko. 1844. Saint-Petersburg", 1845), N.A.Nekrasov ("From the Editor", 1850), A.V.Druzhinin (letters XXIII and XXV of the cycle "Letters of the Nonresident Subscriber", 1851; an introduction to the translation of Shakespeare's "King Lear", 1856), each of which, giving in general a favourable response of Marlowe's drama, expressed thoughts directly or indirectly underlining the necessity of further understanding of the creative work of the talented dramatist of the Elizabethan time by Russian poets, translators, literary critics.

\section{Conclusions}

Initial interest to Christopher Marlowe's creative work in Russia which emerged at the end of the 1820-s and was conditioned by the publication of the German romanticist L.Tieck's tale "The Poet's Life" ("Dichterleben") translation which presented Shakespeare and writers of his time in the 1830 - 1850-s was significantly backed up with publications of translated articles on literary criticism devoted to English drama of the end of the XVIth century. The majority of these articles had compilative character and based on materials borrowed in European editions. At the same years Marlowe's creative work got responses of the leading Russian writers I.S.Turgenev ("Faust, a Tragedy. Goethe's Work. The Translation of the First Part and Summary of the Second One. M.Vronchenko. 1844. Saint-Petersburg", 1845), N.A.Nekrasov ("From the Editor", 1850), A.V.Druzhinin (letters XXIII and XXV of the cycle "Letters of the Nonresident Subscriber", 1851; an introduction to the translation of Shakespeare's "King Lear", 1856). Though these responses were characterized with fragmentation, lack of systematic nature in reception it should be admitted that Marlowe was no longer evaluated as a peripheral writer, was more often characterized as Shakespeare's direct predecessor, a person with an extraordinary gift.

In some time the author of the first material on literary criticism in Russia about Christopher Marlowe's creative work S.F.Uvarov in his essay "Marlowe, one of Shakespeare's Predecessors" published in "Russkoye Slovo" ("Russian Word") in 1859 considered the evolution of Marlowe's drama creative work, his methods of English drama modernization, significance of his merits in Shakespearean theatre development. S.F.Uvarov's essay material was used by V.P.Botkin while preparing the article "Literature and Theatre in England before Shakespeare" which preceded the first volume of the first Russian "Complete Set of Drama Works by Shakespeare in Russian Writers' Translations" edited by N.V.Gerbel and N.A.Nekrasov in $1865-1868$.

\section{Acknowledgements}

The research has been carried out within the project 2232 "Interdisciplinary social and humanist research in the context of innovative development and international connections" in the basic part of the state quota of the RF Department of 
Education and Science.

\section{References}

Alekseyev, M. P. (1982). Russian-English literary relations (the XVIIIth century - first half of the XIXth century). (Literature heritage. Vol. 91). Moscow: Nauka (Science).

Anikin, G. V., \& Mikhalskaya, N. P. (1975). History of English literature. Moscow: Vysshaya shkola (Higher school).

Anikst, A. A. (1965). The theatre of Shakespeare's epoch. Moscow: Iskusstvo (Art).

Bagno, V. E. (2006). Russia and Spain: a common border. Saint-Petersburg: Nauka (Science).

Balashov, N. I. (1998). A word in defense of Shakespeare. Moscow: Academic notebooks.

Bartoshevich, A. V. (1985). Shakespeare on the English stage. The end of the XIXth - first half of the XXth century. Life of traditions and fight of ideas. Moscow: Nauka (Science).

Batyuto, A. I. (1961). <Comments to the letter of I. S. Turgenev to T. N. Granovskiy dating May 18 (30), 1840>. In I. S. Turgenev, A complete set of works and letters: In 28 vol. Letters: In 13 vol. Vol. 1. Letters. 1831 - 1850. (pp. 529-531). Moscow-Leningrad: Academy of Sciences of the USSR publishing-house.

Boyadzhiev, G. N. (1973). Ever-beauteous theatre of Renaissance epoch: Italy, Spain, England. Leningrad: Iskusstvo (Art).

Chasle, Ph. (1837). Drama morals of the XVIth century. Translated from French by M. Stroyeva. Moscow Observer, XII, 6, 2, 215-244.

Chasle, Ph. (1852). The English theatre before Shakespeare. Translated from French. Pantheon, IV, 8, 43-54; V, 9, 1-46; 10, 1-28.

Chernyshevskiy, N. G. (1949). A letter to M. L. Mikhailov (1850). In N. G. Chernyshevskiy, A complete set of works: In 15 vol. Vol. XIV. Letters. 1838 - 1876. (pp. 204-210). Moscow: State publishing-house of belles-lettres.

Druzhinin, A. V. (1865a). An introduction to the tragedy "King Lear". In A. V. Druzhinin, N. V. Gerbel (Ed.), A set of works: In 8 vol. Vol. 3. (pp. 3-52). Saint-Petersburg: Emperor Academy of Sciences printing-house.

Druzhinin, A. V. (1865b). Letters of the nonresident subscriber. 1851: [Letter XXIII. Junuary; Letter XXIV. February; Letter XXV. March; Letter XXVI. December]. In A. V. Druzhinin, N. V. Gerbel (Ed.), A set of works: In 8 vol. Vol. 6. (pp. 460-570). Saint-Petersburg: Emperor Academy of Sciences printing-house.

Dzhivelegov, A. K. (1943). Shakespeare's predecessors. In History of English literature: In 3 vol. Vol. 1. Ed. 1. (pp. 316-379). MoscowLeningrad: Academy of Sciences of the USSR publishing-house.

[Eckstein, F.] (1831). About drama poetry in England before Shakespeare and about Shakespearean drama. Moscow Telegraph, XL, 13, 63-93; 14, 214-242.

Etkind, E. G. (1973). Russian poets-translators from Trediakovskiy to Pushkin. Leningrad: Nauka (Science).

Fedorov, A. V. (1983). Basics of general theory of translation (Linguistic problems). (4th ed., revised and enlarged). Moscow: Vysshaya shkola (Higher school).

Gachechiladze, G. G. (1980). Literary translation and literature relations. Moscow: Sovetskiy Pisatel (Soviet Writer).

Gasparov, M. L. (1989). An essay on history of European verse. Moscow: Nauka (Science).

Girivenko, A. N. (2002). From the history of Russian literary translation of the first half of the XIXth century. Romanticism epoch. Moscow: Flinta; Nauka (Science).

Gorbunov, A. N. (2006). Law instead of grace: Chaucer, Marlowe, Shakespeare. In A.N.Gorbunov, Shakespere's contexts. (pp. 146177). Moscow: MediaMir (MediaWorld).

Knoll, R.E. (1969). Christopher Marlowe. New York: Twayne Publishers.

Kocher, P.H. (1962). Christopher Marlowe. A Study of his Thought, Learning and Character. New York: Russell \& Russell.

Kozmin, B. P., \& Kusheva, Ye. N. (1949). Comments. In N. G. Chernyshevskiy, A complete set of works: In 15 vol. Vol. XIV. Letters. 1838 - 1876. (pp. 772-855). Moscow: State publishing-house of belles-lettres.

Kuchelbecker, W. K. (1979). A journey. A diary. Articles. (Prepared by N. V. Korolyova, V. D. Rak). Leningrad: Nauka (Science).

Kuriyama, C.B. (1980). Hammer or Anvil: Psychological Patterns in Christopher Marlowe's Plays. New Brunswick: Rutgers University Press.

Leishman, J.B. (1962). The Monarch of Wit: An Analytical and Comparative Study of the Poetry of John Donne. London: Hutchinson Press.

Levin, H. (1964). The Dead Shepheard. In H. Levin, C. Leech (Ed.), Marlowe. A Collection of Critical Essays. (pp. 15-28). Englewood Cliffs: Prentice-Hall.

Levin, Yu. D. (1985). Russian translators of the XIXth century and literary translation development. Leningrad: Nauka (Science).

Levin, Yu. D. (1965). The sixties. In M. P. Alekseyev (Ed.), Shakespeare and Russian culture. (pp. 407-543). Moscow-Leningrad: Nauka (Science).

Linnichenko, A. I. (1860). The course on history of poetry for Women's Institutes students and Gymnasiums students. Kiev: University printing-house.

Literature newspaper. (1841). About dramatists, Shakespeare's contemporaries. Literature newspaper, 120, 478-479; 121, 483-484.

Melgunov, B. V. (1997). <Comments to the editor's note "Literature news" (Sovremennik (Contemporary). - 1858. - №5. - Section II. P. 68)>. In N. A. Nekrasov, A complete set of works and letters: In 15 vol. Vol. 13. Book 1. Materials of editorial and publishing activity. (pp. 435-436). Saint-Petersburg: Nauka (Science).

Mikeladze, N. E. (2005). Shakespeare and Machiavelli: The theme of "machiavellianism" in Shakespearean drama. Moscow: "VK" publishing-house. 
Morozov, M. M. (1941). Comments to Shakespeare's plays. Moscow-Leningrad: All-Russian theatre society.

Nekrasov, N. A. (1997). From the editor. In N. A. Nekrasov, A complete set of works and letters: In 15 vol. Vol. 13. Book 1. Materials of editorial and publishing activity. (pp. 96-97). Saint-Petersburg: Nauka (Science).

Nelyubin, L. L., \& Khukhuni, G. T. (2008). The science of translation (history and theory from ancient times to the present day). (2nd ed.). Moscow: Flinta; MPSI.

Ovchinnikova, F. G. (1965). Shakespeare's contemporaries and Russian translators: (About one-volume edition of Ch.Marlowe). In The skill of translation. 1964: Collected articles. Ed. 4. (pp. 168-203). Moscow: Sovetskiy Pisatel (Soviet Writer).

Pantheon of Russian and all European theatres. (1841). About theatres in London in Shakespeare's time. Pantheon of Russian and all European theatres, III, 8, V, 69-74.

Parfenov, A. T. (1964). Christopher Marlowe. Moscow: Belles-lettres.

Partnership "Progress of our life". ([1908]). Foreign criticism about Turgenev. (Translated by E. I. Sh.; 2nd ed.). Saint-Petersburg: Partnership "Progress of our life".

Pinskiy, L. E. (1971). Shakespeare. Drama fundamentals. Moscow: Belles-lettres.

Samarin, R. M. (1964). Shakespeare's realism. Moscow: Nauka (Science).

Sha, T. [Show, T.] (1847). The essay on English literature. The first and second articles. Library for reading, 83, V, 1-36.

Shvedov, Yu. F. (1975). Shakespeare's tragedy evolution. Moscow: Iskusstvo (Art).

Smirnov, A. A. (1963). Shakespeare. Leningrad-Moscow: Iskusstvo (Art).

Storozhenko, N. I. (1872). Shakespeare's predecessors: An episode from the history of English drama in Elizabethan epoch. Vol. 1. Lilly and Marlowe. Saint-Petersburg: V.Demakov's printing-house.

Tulov, M. A. (1853). A guide to understanding kinds, genres and forms of poetry. Kiev: University printing-house.

Turgenev, I. S. (2002). A letter to Pauline Viardot dating June, 21 - 22 (July, 3 - 4) 1874. In I.S. Turgenev, A complete set of works and letters: In 30 vol. Letters: In 18 vol. Vol. 13. Letters. 1874. (pp. 121-124). Moscow: Nauka (Science).

Turgenev, I. S. (1961). A letter to T. N. Granovskiy dating May 18 (30), 1840. In I. S. Turgenev, A complete set of works and letters: In 28 vol. Letters: In 13 vol. Vol. 1. Letters. 1831 - 1850. (pp. 187-190). Moscow-Leningrad: Academy of Sciences of the USSR publishing-house.

Turgenev, I. S. (1978). Faust, a tragedy. Goethe's work. The translation of the first part and summary of the second one. M. Vronchenko. 1844. Saint-Petersburg. In I. S. Turgenev, A complete set of works and letters: In 30 vol. Works: In 12 vol. Vol. 1. Verses, poems, articles and reviews, prosaic sketches. 1834 - 1849. (pp. 197-235). Moscow: Nauka (Science).

Veselovskiy, Alexander N. (1940). Historical poetics. (Ed., an introduction and comments by V. M. Zhirmunskiy). Leningrad: State publishing-house of belles-lettres.

Veselovskiy, Alexey N. (1906). Western influence in new Russian literature. (3rd ed., revised). Moscow: I. N. Kushnerev and Co typolithography.

Weil, J. (1977). Christopher Marlowe: Merlin's Prophet. Cambridge: Cambridge University Press.

Zaborov, P. R. (1978). French correspondents of A. I. Turgenev: (M. A. Julien, E. Ero, P. S. Balansh, F. Eckshtein). In An annual journal of the handwritten department of Pushkin's House for 1976. (pp. 258-275). Leningrad: Nauka (Science).

Zhatkin, D. N. (2008). English Romanticism poetry in Russian translations of the 1840 - 1850-s. Herald of Moscow State Regional University. Series Russian philology, 3, 137-144.

Zhatkin, D. N., \& Dolgov, A. P. (2007). Peri in Russian poetry. Russian Speech, 3, 3-8.

Zhatkin, D. N., \& Orlova, N. Yu. (2010). N. V. Gerbel as a translator of fragments from Christopher Marlowe's play "Edward II". Cultural life of the south of Russia, 3(37), 58-60. [Online] Available: http://elibrary.ru/download/75314767.pdf (February 4, 2015)

Zhirmunskiy, V. M. (1979). Comparative literature study. East and West. Leningrad: Nauka (Science). 
ISSN 2039-2117 (online) ISSN 2039-9340 (print)
Mediterranean Journal of Social Sciences MCSER Publishing, Rome-Italy
Vol 6 No $3 \mathrm{~S} 3$ May 2015 